\title{
The role of thrombocyte serotonin system and some thrombocyte characteristics in treatment of depressive patients with cardiovascular diseases
}

\author{
Lidija Kostanjšak ${ }^{1}$, Davor Zdunić ${ }^{2}$ \\ ${ }^{1}$ Acute Psychiatric Unit, University Hospital Campus, Ennis, Co. Clare, Ireland, ${ }^{2}$ Depart- \\ ment of Psychiatry, Sestre milosrdnice University Hospital Center, Zagreb, Croatia
}

\begin{abstract}
Serotonin has an important role in the development of depressive disorders. Bearing in mind that direct testing of central nervous system is unavailable to researchers due to the inability to reach the samples, ever greater attention is given to the peripheral systems that can help us diagnose and detect changes of the disease, but also follow the course of its treatment and recovery. Thrombocyte is a blood cell that contains serotonin lodged in its delta granules. Thrombocyte serotonin system is similar, although not the same as the serotonin system in central nervous system. The most important differences are that in thrombocytes, serotonin is broken down by the enzyme monoaminooxidase $\mathrm{B}$ (MAO-B), while that function in neuron is carried out by monoaminooxidase A (MAO-A) and that a thrombocyte cannot synthetize serotonin itself, because it lacks tryptophan hydroxylase. Nowadays, in the treatment of depressive disorders, mostly the selective inhibitors of serotonin uptake (SIPPS) are being used. The research has proved that therapy with those medications changes the concentration of serotonin in thrombocytes and changes the values of some thrombocyte indices. The thrombocyte serotonin is a powerful vasoconstrictor, which increases the cardiovascular risk and the probability of thrombogenesis. The mean volume of thrombocytes (MPV) is a positive index of thrombocyte activity and the increase of MPV represents an independent risk factor for the development of cardiovascular diseases. It is of enormous significance to recognize the depression in patients who suffer from cardiovascular diseases. Depression interferes with the recovery of those patients, because it reduces the personal engagement in it and disturbs patients' compliance and the motivation for treatment. Besides the fact that the treatment with SIPPS leads to the regression of symptoms of depression, it also changes the concentration of thrombocyte serotonin and the mean volume of thrombocytes towards the values that reduce their role in pathogenesis of cardiovascular diseases, thus reducing the risk of re-occurrence of cardiovascular incidents and improving the patients' recovery.
\end{abstract}

Keywords: Serotonin, Thrombocytes, SIPPS, Depression, Cardiovascular diseases

Copyright (C) 2017 KBCSM, Zagreb

e-mail: alcoholism.kbcsm@gmail.com • www.http//hrcak.srce.hr/acoholism

Correnspodence to: Lidija Kostanjšak, M.D.

Acute Psychiatric Unit, University Hospital Campus

Ennis, Co. Clare, Ireland

e-mail: dr.kostanjsak@gmail.com 


\section{Introduction}

Among the known neurotransmitters, serotonin, norepinephrine and dopamine play the important roles in the development of psychiatric disturbances. The research so far has shown that this is not the matter of concentrations themselves, but of disbalance of concentrations between the neurotransmitter systems in CNS (central nervous system). There is proof that there is a decrease of serotonin, epinephrine and dopamine functions in patients suffering from the recurring depressive episodes, while there is a hyperactivity of norepinephrine and dopamine system in patients suffering from the bipolar affective disorder [1]. There is still a dilemma if there were a hypo or hyperactivity of serotonin system in generalized anxiety disorder $[2,3]$. The agonists of $5 \mathrm{HT}_{1 \mathrm{~A}}$ receptors reduce the symptoms of panic disorders, while the activation of $5 \mathrm{HT}_{2 \mathrm{C}}$ receptors induces a panic attack [4]. Hypersensitivity of postsynaptic serotonin receptors plays an important role in obsessive-compulsive disorders [5]. Destabilization of serotonin system has been noted also in posttraumatic stress disorders. This fact had been confirmed by the efficiency of SIPPS in its treatment [6]. Dysfunction of serotonin system is also present in some personality disorders, urge-control disturbances, feeding disorders and dementia. It seems that the negative symptoms in schizophrenia are due to a dysfunction of serotonin system. In suicidal tendencies, the role of serotonin system is of the greatest importance and numerous post-mortem investigations had revealed lower concentrations of serotonin and its main metabolite 5-hydroxyindolacetate acid (5-HIAA) in brainstem, nuclei raphe, putamen and hypothalamus [7]. Some research show that lower levels of thrombocyte serotonin are connected with suicidal behaviour of depressive patients [8]. Numerous investigations have shown that, among the patients who had suffered a myocardial infarction or other diseases of cardiovascular system we can find depressive symptoms in the frame of depressive reaction, but also a real depression in its fully-blown clinical form. Depression slows the recovery in those patients but, even more importantly, some indices had been found in patients suffering from depression that it could be directly connected with an increased risk for the development of cardiovascular diseases and complications during recovery. Thrombocyte serotonin is a strong vasoconstrictor and the research has shown that the treatment with selective inhibitors of serotonin uptake (SIPPS) causes lowering of its concentration, thus reducing its role in increasing the cardiovascular risk and causing the complications of recovery. Also, the treatment of depressive patients with SIPPS lowers the values of MPV (mean platelet volume, mean thrombocyte cell volume), which had been recognized as an independent risk factor for the development of myocardial infarction and stroke.

\section{Serotonin system in thrombocytes}

Enterochromafine cells are the only cells besides 5HT neurons, that synthetize serotonin. They release it into the blood stream, from where it, bound to its transporter, goes mostly into the thrombocytes. Serotonin system in thrombocytes is very similar to the one in neurons. It is a part of the mechanism of thrombocyte response, which is actually a process of shape change and aggregation of thrombocytes $[9,10]$. Thrombocytes contain about $99 \%$ of total serotonin in circulation, so in physiological conditions, plasma levels of serotonin reflect the concentration of serotonin in thrombocytes. Human throm- 
bocytes contain averagely 150 to $600 \mathrm{ng}$ of serotonin $/ 10^{9}$ thrombocytes [11]. Serotonin system of thrombocytes is made of: serotonin transmembrane carrier (transporter), serotonin receptor, enzyme monoaminooxidase and serotonin stored in delta granules. Serotonin enters the thrombocytes and aggregates through actions of two carriers [12]. Protein 5-HT carrier (5HTt) is located at the membrane of thrombocyte and enables the intake of serotonin and other endogenous amines, for example dopamine, from plasma to the cytoplasmic fluid of thrombocytes [13]. After the active transport, serotonin can be partly subjected to enzymatic breakdown, catalyzed by MAO-B enzyme, located at the external side of membrane of thrombocyte mitochondria and partly stored in delta granules. Storage in delta granules is carried out through so called vesicular transporter, located at the membrane of the granules. This active transport is enabled by the highly efficient proton ATP-aze [14-16]. This mechanism is equal to the serotonin intake in neuron vesicles. In the complicated process of blood coagulation, serotonin is also involved. During the process of coagulation, serotonin is released from delta granules of thrombocytes by process of exocytosis. Similarly, be means of exocytosis, serotonin is released from the synaptic vesicles during the chemical transmission. The research so far had revealed 15 different $5 \mathrm{HT}$ receptors and they all belong to the family of $G$ protein receptors, while on the surface of thrombocytes, there is only $5 \mathrm{HT}_{2 \mathrm{~A}}$ receptor, which is the binding place for serotonin and antidepressants - inhibitors of serotonin active transport [17]. Binding of serotonin, as an agonist of $5 \mathrm{HT}$ receptors, induces the thrombocytes' response, consisting of release reaction and increased aggregation of thrombocytes, during which the thrombocytes also change their shape. Serotonin also shows the ability to strengthen the thrombocytes' response in the presence of other agonists. Antagonists of $5 \mathrm{HT}_{2 \mathrm{~A}}$ receptors at the periphery show an anti-migraine effect. They are also used in the treatment of asthma and for controlling the carcinoid tumors [18]. In $\mathrm{CNS}, 5 \mathrm{HT}_{2 \mathrm{~A}}$ receptors are located in the cortex and play a role in sensory perception. Activation of those receptors is connected with the loss of appetite and the occurrence of anxiety and panic [19]. Antagonists of $5 \mathrm{HT}_{2 \mathrm{~A}}$ receptors in CNS show an antidepressive, but also antipsychotic, anxiolytic and hypnotic effect.

\section{Development of thrombocytes and thrombocyte indices}

The lifespan of thrombocytes in the peripheral blood flow equals 9-11 day [20]. Normal number of thrombocytes is $250 \times 10$ na 9 $/ \mathrm{L}$, mean diameter is about 1-2 micrometers and the mean cell volume is $8 \mathrm{fl}$. Thrombocytes are the only blood cells that reach their full number already in the fetal blood [21]. Pluripotent stem hematopoietic cell is the destination cell, which differentiates in immature cells of myelopoetic and lymphopoetic system, from which the functionally mature cells, like erythrocytes, granulocytes, monocytes, thrombocytes and lymphocytes T, get differentiated through the processes of proliferation and maturation. The least mature cell that shows the morphological characteristics of the thrombocyte strain is a megakaryoblast. The next developmental form is a megakaryocyte, which is the biggest hematopoietic cell, already containing the thick granules or delta granules, filled with, among other things, serotonin. Megakaryocyte is a cell that does not proliferate. It has got multiple 
endomytoses and a very high DNA content. The final destiny of megakaryocytes during maturation is releasing the thrombocytes into the bloodflow.Prothrombocyte theory implies the creation of prothrombocyte through the long protrusions of the cytoplasm of megakaryocytes. In the final stage, which lasts about 5-10 hours in already converted cytoplasm with intracellular content, the filaments connect the already formed thrombocytes with the cytoplasm of prothromobocytes, and after these filaments are ruptured, thrombocytes get released to the blood flow. From the beginning of differentiation of the hematopoietic stem cell to the creation of thrombocyte, about ten days pass. Each megakaryocyte creates 5-10 thousands of thrombocytes. They are shaped like a disk and contain neither nucleus, nor endoplasmic reticulum and Golgi bodies. Glycocalix is a fluffy wrapping that covers the peripheral zone of thrombocytes. It contains plasma proteins and factors of coagulation, fibrinolysis and complement. Below the glycocalix is a negatively charged thrombocyte membrane, consisting of conglomerates of lipid and protein moleculesol-gel zones. Through the membrane of thrombocytes, the substances from thrombocyte granules are being released to bloodstream, but some substances are also actively carried inside, including serotonin. The thrombocyte skeleton is a thick tubular system consisting of filaments and microtubules. It is important for storing and regulation of calcium ion levels and synthesis of prostaglandins, thromboxane and cyclooxygenasis [22]. There is another system of microfilaments which takes part in contraction and secretion of thrombocytes and causes the shape change. In the zone of organelles inside the thrombocytes there are alpha granules which contain adhesive proteins, growth factors and coagulation factors and delta granules which, besides other active substances and metabolites, contain ATP and serotonin. Thrombocyte lysosomes contain hydrolytic enzymes and peroxisomes with catalase. They have a key role in the process of hemostasis. Qualitative indices of thrombocytes are: number of thrombocytes (Plt), mean volume of thrombocytes (MPV) and thrombocrite (Pct), routinely available index of heterogeneity of thrombocytes is thewidth of distribution per volume (PDW).

The number of thrombocytes (Plt) is the absolute number of circulating thrombocytes per unit of blood volume. Physiological values span from $150-400 \times 10^{9} / \mathrm{L}$. The mean volume of thrombocytes - MPV (mean platelet volume) is expressed in femtoliters (fL) and its clinical significance lies in the fact that bigger thrombocytes are more reactive and cause creation of more thrombogenic factors [23,24].

The research has been directed towards determining the clinical significance of MPV as a potential predictive index of thrombocyte activation, as a link in the activation of atherosclerosis pathogenesis and the development of the acute coronary syndrome. Thrombocrite (Pct) represents a volume part of thrombocytes per volume unit of blood. It is calculated as a product of multiplication of MPV and the number of thrombocytes. The reference interval spans from $0.214 \pm 0.40 \%$ [25]. The distribution of thrombocytes per volume - PDW (platelet distribution width) is a measure of heterogeneity of thrombocytes by size. It is used in clinical practice for the differential diagnosis of reactive and primary thrombocytosis [26]. 
Thrombocyte serotonin and thrombocyte characteristics in the neurobiology of depression and cardiovascular diseases - review of the research so far

The possibilities for exploring the serotonin system in CNS are limited, because of the complicated access to samples needed for the analysis, which is why the focus of investigation has been turned to the investigation of elements of thrombocyte serotonin system. The similarity of these two serotonin system has been discovered at the end of the previous century [27]. The similarity between the basic elements has been established: enzyme monoaminooxidase, serotonin transporter and $5 \mathrm{H}^{\top} \mathrm{T}_{2 \mathrm{~A}}$ receptors. The reason why we cannot speak of being identical, but only similar is the fact that serotonin in thrombocytes is metabolized by MAO-B, while in neurons, it is metabolized by MAO-A. The further difference is that a thrombocyte cannot synthetize serotonin itself, because of the lack of tryptophan hydroxylaze [28,29]. Thrombocyte serotonin represents an easily accessible biological index, and numerous studies were designed to investigate its relations with various forms of the depressive disorder, suicidal behaviour and if there was a connection between it and the response to pharmacotherapy [30]. In some of the studies made so far, the results have shown that, in the patients suffering from the major depressive disorder, there is a lower level of thrombocyte serotonin and that the therapy with antidepressants changes some thrombocyte indices. The Takakshi study, from 1976, made on 20 patients with unipolar depression and 19 patients with involutive depression, 20 of which had just suffered their first depressive episode, compared to 118 healthy subjects showed that the concentration of thrombocyte serotonin is lower in patients with unipolar and involutive depression compared to the healthy volunteers [31]. Samas study, from 1987, made on 18 patients suffering from melancholy and compared to 20 healthy volunteers showed that the concentration of thrombocyte serotonin is significantly lower in patients suffering from melancholy compared to the healthy volunteers [32]. Quintana study, from 1992, done on 25 untreated depressive patients, compared to 25 healthy volunteers showed that the concentration of thrombocyte serotonin is lower in depressive patients [33]. The study of Maurej-Spurej et al. from 2004, carried out on 27 depressive patients, 13 of which had been untreated and 14 had been taking SIPPS, showed a lower concentration of thrombocyte serotonin in the untreated depressive subjects [34]. In the study presented by Ataoglu and Canan in 2009, they had followed 15 patients suffering from the major depressive disorder, compared them to the group of healthy volunteers and found out that MPV was significantly higher in the group of depressive patients, but no significant difference had been found between the patients and the control group considering the number of thrombocytes [35]. A significant reduction of MPV, but also a significant reduction of the number of thrombocytes had been found even after an eight-week treatment with escitalopram. MPV values had stayed higher compared to the control group even after eight weeks of treatment. Patients who had suffered a myocardial infarction and those with the unstable angina pectoris display increased values of MPV compared to the patients suffering from the stable angina pectoris and compared to the patients with chest pain of non-cardiac origin. An increase 
of MPV has been even recognized as an independent risk factor for the development of myocardial infarction or stroke [36]. In the study of Canan et al. from 2011, the authors investigated the relation between MPV, as an index of the activity of thrombocytes and depression in the adult population of Turkey [37]. The study included 2286 subjects and revealed significantly higher values of MPV in patients suffering from depression compared to the control group of healthy volunteers. After the exclusion of other parameters that could cause the elevation of MPV level, the value of MPV in depressive patients was still elevated. In the study made by Song et al. in 2012, the authors measured the number of thrombocytes after the treatment with escitalopram, venlafaxine and bupropion and found a significantly reduced number of thrombocytes after one month of therapy with escitalopram, while there had been no significant changes after the treatment with other two medications [38].

\section{Selective inhibitors of serotonin re-uptake}

Antidepressants represent a various group of medications with different mechanisms of action. The tricyclic antidepressants have a prominent place among them, because they had served as a base for further research. It was through them that the importance of inhibition of serotonin and norepinephrine reuptake had been determined, as a base for the antidepressant action. However, since they have a very wide profile of adverse effects, they belong among the medicaments that are not so well tolerated. Considering the antidepressant effect itself, we have not gone much further from the tricyclic antidepressants but, on the other hand, the new medi- cations are better tolerated, which enhances the compliance of patients, thus making the course of therapy easier and more secure in given time. The most widely used drugs from this group are SIPPS, which are very similar to each other and do not differ significantly in their antidepressive affect, but do differ in the profile of their adverse effects. The mechanism of action of SIPPS is blocking the serotonin transporter. The process in central nervous system occurs in various areas of the brain where the serotoninergic neurons originating from nuclei raphe end. Antidepressive effect is achieved when the serotonin transporter is about $80 \%$ blocked. As a consequence, an increase of serotonin on the synapse occurs, affecting the postsynaptic $5 \mathrm{HT}_{2 \mathrm{~A}}, 5 \mathrm{HT}_{2 \mathrm{C}}$ and $5 \mathrm{HT}_{3}$ receptors, resulting in some adverse occurrences in the first weeks of medication. The agonist effect of SIPPS on post-synaptic $5 \mathrm{HT}_{1 \mathrm{~A}}$ and $5 \mathrm{H}_{4}$ receptors leads towards the antidepressive and anxiolytic effect. In the beginning of medication, SIPPS also cause the stimulation $5 \mathrm{HT}_{1 \mathrm{~A}}$ pre-synaptic autoreceptors, causing the reduction of serotonin neurons' activity. Several weeks later, the desensitization of postsynaptic serotonin receptors occurs, leading to the alleviation or the entire regression of adverse effects. The beginning of antidepressive action is connected with returning the activity of serotoninergic neurons back to normal and then increased, due to the desensitization of pre-synaptic $5 \mathrm{HT}_{1 \mathrm{~A}}$ receptors. However, it is estimated that in $30-50 \%$ of patients, SIPPS will show no antidepressive effect. That is why the medications with different mechanisms of action are used. The following SIPPS drugs are registered in our Country and the primary characteristics in which they differ are: 1. Fluvoxamine - the greatest affinity for sigma receptors, their 
stimulation leads to an increase of cholinergic and glutaminergic transmission, which has an important influence on cognitive functioning [39]. 2. Fluoxetine - inhibitor of serotonin $5 \mathrm{HT}_{2 \mathrm{C}}$ receptors, leading to a beneficial effect on slow-wave sleep, improvement of cognitive functions, antidepressive effect and moderate influence on MAO-A and MAOB [40].3. Paroxetine - moderate affinity to noradrenergic receptors, anticholinergic effect, both effects dose-dependent, the most potent SIPPS., 4. Sertraline - inhibiting the dopamine transporter, increases the level of dopamine in nucleus accumbens, affects the sigma receptors and the adrenergic alpha 1 receptors [41]. 5. Citalopram - very strong inhibitor of serotonin reuptake, the strongest affinity for $\mathrm{H}_{1}$ histamine receptors of all SIPPS, with higher doses, one has to consider sedation and body weight increase. 6 . Escitalopram - the most selective inhibitor of serotonin reuptake, does not affect any other receptors, transporters or enzymes, even in the highest doses.

The differences between the SIPPS medications mentioned originate from their pharmacokinetic characteristics. The elimination half-time for citalopram, sertraline, fluvoxamine and paroxetine equals 24 hours, while fluoxetine is an exception and its half-life equals 2-4 days for itself and 7-15 days for its metabolite, norfluoxetine. The significant differences stem from the ability of each SIPPS to inhibit the enzymes CYP 450, while fluvoxamine is the least selective and can drastically increase the concentration of drugs which are metabolized through CYP 3A4. Paroxetine influences the CYP 2D6 enzyme and its inhibition lasts about 3 days [42].

As we already mentioned, in certain number of patients with depression, SIPPS will not achieve the desired regression of depres- sive symptoms and it's then when we turn to the medications with different mechanisms of action. The characteristics of other groups of antidepressants are 1.dual inhibitors of serotonin and norepinephrine reuptake: venlafaxine - in lower doses, affects only the serotonin transporter, while in higher doses it affects also the noradrenergic receptor; that effect is achieved through blocking the MAO-B enzyme; duloxetine - registered also for the treatment of neuropathic pain; that effect is achieved through blocking both serotonin and noradrenergic transporter [43]. The noradrenergic and the specific serotoninergic $5 \mathrm{HT}_{2 \mathrm{~A}}$ and $5 \mathrm{HT}_{2 \mathrm{C}}$ blocker (NAS$\mathrm{SA}$ ): mirtazapine - dose-dependent action, acts as a histamine receptor blocker (in lower doses), serotonin $5 \mathrm{HT}_{2 \mathrm{~A}}$ and $5 \mathrm{HT}_{2 \mathrm{C}}$ receptors (medium doses), adrenergic alpha 2 receptors (higher doses). The modulators of serotonin intake: tianeptine - mechanism of action is insufficiently known, it is believed that it acts in such manner as to reduce the quantity of available serotonin by means of increasing the serotonin reuptake to neurons. Agonist of melatonin $\mathrm{MT}_{1}$ and $\mathrm{MT}_{2}$ receptors and the antagonist of $5 \mathrm{HT}_{2 \mathrm{C}}$ receptors- agomelatine - has no effect on other receptors and its antidepressive action is the result of interaction between the receptors mentioned, while agomelatin does not affect the level of serotonin, but changes the level of increasing the dopamine and norepinephrine and affects the neuroplasticity [44].

When using the drugs which affect the serotonin system, one should be very careful not to cause the development of toxic serotonin syndrome, which occurs because of an increased serotonin activity and hyperstimulation of serotonin receptors, particularly $5 \mathrm{HT}_{1 \mathrm{~A}}$ in spinal cord and brainstem. The increase of norepinephrine, glutamate 
and dopamine release, as a consequence of an increased serotonin activity, also produces symptoms in the frame of a toxic serotonin syndrome [45].

\section{Discussion and conclusions}

Considering the fact that the course of recovery from many diseases can be complicated by the occurrence of depression, which is particularly accentuated in cardiovascular diseases, timely recognition and successful treatment of depression directly influences the course of recovery and finally, the mortality, because the depression is related to the increased mortality in those patients. Besides the fact that the depressive behaviour disturbs the recovery of patients, it also reduces the personal engagement in recovery, compliance and motivation of patients, which is a very important role, but an important role belongs also to the thrombocyte serotonin in pathogenesis of cardiovascular diseases, especially the coronary heart disease and its complications. The thrombocyte serotonin is one of the factors in coagulation process, which is, on the other hand, one of the most important mechanism that connect depression with the coronary heart disease. The prevalence of depression in patients with coronary heart disease spans from 16-23\%. Numerous studies have shown that besides hyperlipidemia, hypertension, obesity, diabetes and smoking, depression also represents an independent risk factor for the development of coronary heart disease [46]. The presence of depression is a bad prognostic sign for patients who had already suffered a heart attack. The depressive patients have 3-4 times greater risk of developing the cardiovascular complications compared to the nondepressive patients [47]. Thrombocytes play the central role in the development of ath- erosclerosis, thrombosis and the acute coronary syndromes. It is considered that one of the reasons for the previously mentioned increased risk is a dysfunction, i.e. increased activity of thrombocytes in depressive patients [48]. Serotonin secreted by alpha granules is a very potent vasoconstrictor, which increases the cardiovascular risk and the probability of thrombi formation. Some changes of physiological characteristics of thrombocytes present in depressive patients, such as mobilization of calcium inside the thrombocytes, up-regulation of serotonin receptors and alpha 2 adrenoreceptors, down-regulation of serotonin transporters, changing the signal of the second messenger, i.e. changes of levels of monoamines and cateholamines in thrombocytes can have a negative effect on thrombocyte function, namely strengthen the processes of coagulation and thrombogenesis [49]. Thus, we can conclude that serotonin plays important roles both in the neurobiology of depression and in thrombogenesis [50]. There have been studies that tried to explain the connection between the level of thrombocyte serotonin in the acute coronary syndrome in patients with and without the symptoms of depression and determine if there was a linear correlation between them. In the study made by Sanner et al. in 2013, the authors could not find a linear correlation. The study concludes that the correlation between the thrombocyte serotonin, depressive symptoms and the acute coronary syndrome is not yet fully explained, but there is a number of clues that suggest such correlation [51]. The SIPPS act in such manner that their action reduces the level of the available serotonin, which is reflected in lower levels of serotonin in thrombocytes. The data for individual SIPPS suggest that, for example, sertraline in vitro causes 
the inhibition of thrombocyte aggregation, depending on its dose [52]. After six weeks of therapy with paroxetine, a normalization of thrombocyte activity can be observed in depressive patients, both in those with and those without the coronary heart disease [53]. Similarly. The study made by Glassman et al in 2002 showed that the depressive patients who had suffered a heart attack and had been treated with sertraline during the period of 24 weeks had a smaller number of the acute coronary incidents compared to patients who had been treated with placebo [54]. However, the difference was not statistically significant, but considering the high incidence of cardiovascular diseases (especially ischemic heart disease) in population, even such difference should not be neglected.

A positive index of thrombocyte activity is MPV [55]. In the study by Ataoglu and Canan from 2009, the results have shown a decrease of MPV values after an eight-week treatment with escitalopram. The increased values of MPV have been detected in patients with unstable angina pectoris and patients who had suffered a heart attack. That is why an increase of MPV has been recognized as an independent risk factor for the development of both stroke and a heart at-

\section{References}

1. Lopez Figueroa AL, Norton CS, Lopez Figueroa MO, Armellini-Dodel D, Burke S, Akil H, et all. Serotonin $5 \mathrm{HT}_{1 \mathrm{~A}}, 5 \mathrm{HT}_{1 \mathrm{~B}}$ and $5-\mathrm{HT}_{2 \mathrm{~A}}$ receptors mRNA expression in subjects with major depression, bipolar disorder and schizophrenia. Biol Psychiatry. 2004;55:225-33.

2. Tauscher GD, Klein N, Kapur S. Functional neuroimaging in psychiatry. In Panksepp J, editor. tack [56]. It has been proved that the size of thrombocytes, measured as a mean value of thrombocytes' volume (MPV) is correlated with their reactivity [57].

In concordance with the facts listed above, we are at liberty to conclude that the timely detection of depression in patients with cardiovascular diseases is, particularly after the coronary incidents, of the utmost importance. The treatment of depression directly influences the recovery of those patients and reduces the incidence of complications. The antidepressants from SIPPS group has a special role in the treatment of depression. These medications display a positive effect on the recovery through the improvement of mental status and there is also clear evidence that they reduce the concentration of thrombocyte serotonin and the mean volume of thrombocytes, which both have an important role in pathogenesis of cardiovascular diseases.

\section{Acknowledgements}

None

\section{Conflict of interest}

None to declare
Textbook of Biological Psychiatry. New Jersey: Wiley-Liss Inc.; 2004. p. 167-93.

3. Leonard BE. Psychotropic drugs that modify the serotonergic system. In: Leonard BE, editor. Fundamentals of Psychopharmacology. Chichester, England: John Wiley \& Sons Ltd.; 1997. p. 91-105.

4. Marsden CA. The neuropharmacology of serotonin in the central nervous system. In: Feighner JP, Boyer WF, editors. Selective serotonin inhibi- 
tors. Chichester, England: John Wiley \& Sons Ltd.; 1996. p. 1-33.

5. Stein DJ. Serotonergic Neurocircuitry in Mood and Anxiety Disorders. London, New York: Martin Dunitz; 2003.

6. Hollander E, Simeon D. Anksiozni poremećaji. Jastrebarsko: Naklada Slap; 2006.

7. Arango V, Huang Y, Underwood MD, Mann JJ. Genetics of the serotoninergic system in suicidal behaviour. J Psychiatr Res. 2003;31:1-15.

8. Poeldinger W, Calanchini B, SchwartzA. A functional-dimensional approach to depression: serotonin deficiency as a target syndrome in a comparison of 5-hydroxytryptophan and fluvoxamine. Psychopathology. 1991;24:53-81.

9. Blakely RD, Berson HE, Fremeaut RT, Caron GM, Peek MM, Prince HK, et al. Cloning and expression of a functional serotonin transporter from rabit brain. Nature. 1991;354:66-70.

10. De Clerck F. The role of serotonin in thrombogenesis. Clin Physiol Biochem. 1990;8:40-9.

11. Ortiz J, Artigas F, Gelpi E. Serotonergic status in human blood. Life Sci. 1988;43:983-90.

12. Freyssinet JM. Cellular microparticles: what are they bad or good for? J Thromb Haemost. 2003;1:1655-62.

13. Masson J, Sagné C, Hamon M, El Mastikawy S. Neurotransmitter transporters in the central nervous system. Pharm Rev. 1999;51:439-64.

14. Denney RM, Denney CB. An update on the identity crisis of monoamine oxidase: New and old evidence for the independence of MAO A and B. J Pharmacol Exp Ther. 1985;30:227-58.

15. Van Kempen GMJ, Van Brussel LJ, Pennings EJM. Assay of platelet monoamine oxidase in whole blood. Clin Chim Acta. 1985;153:197-202.

16. Rudnick G, Clarck J. From synapse to vesicle: the reuptake and storage of biogenic amine neurotransmitters. Biochim Biophys Acta. 1993;1144:249-63.

17. Cooper JR, Bloom FE, Roth RH. The biochemical basis of Neuropharmacology. 8th edition. New York: Oxford University Press; 2003.

18. Rang HP, Dale MM, Ritter JM. Pharmacology, 4th edition. Edinburgh: Churcill Livingstone; 1999.

19. Anderson IM, Reid IC. Fundamentals of Clinical Psychopharmacology. London \& New York: Taylor \& Francis Group; 2002.
20. Kile BT. The role of apoptosis in megakaryocytesand platelets. Br J Haematol. 2014;165:217-26.

21. Forestier F, Daffos F, Catherine N, Renard M, Andreux JP. Developmental hematopoiesis in normal human fetal blood. Blood. 1991;77:2360-3.

22. Gerrard JM, White JG, Rao GH, Townsend D. Localization of platelet prostaglandin production in the platelet dense tubular system. Am J Pathol. 1976;101:283-98.

23. Martin JF, Bath PM, Burr ML. Mean platelet volume and myocardial infarction. Lancet 1992;339:1000-1.

24. Thompson CB, Jakubowski JA, Quinn PG, Deykin D, Valeri CR. Platelet size as a determinant of platelet function. J Lab Clin Med 1983;101:205.

25. Shantsila E, Watson T, Yh Lip G. Laboratory investigation of platelets, In: Gresele P, Fuster V, Lopez JA, Page CP, Vermylen J., editors. Platelets in hematologic cardiovascular disorders. Cambridge: Cambridge University Press; 2008. p. 124-7.

26. Osselaer JC, Jamrt J, Scheiff JM. Platelet distribution width for differential diagnosis of thrombocytosis. Clin Chem. 1997;43:1072-6.

27. Pletcher A. Metabolism, transfer and storage of 5-hsydoxytryptamine in bloods platelet. Brit J Pharmacol Chemother. 1968;32:1-16.

28. Erulkar SD. Chemically mediated synaptic transmission: an overview. In: Siegel GJ, Agranoff BW, Albers RW, Molinoff PB, editors. Basic Neurochemistry, 5th ed. New York: Raven Press; 1994. p. 181-208.

29. Stahl SM. Platelets as pharmacological model for the receptor and biochemistry of monoaminergic neurons. In: Longenecker GC, editor. The platelets: physiology and pharmacology. London: Academic Press; 1985. p. 307.

30. Maurer-Spurej E, Pittendreigh C, Solomons K. The influence of selective serotonin reuptake inhibitors on human platetet serotonin. Thromb Haemost. 2004;91:119-2.

31. Takakashi S. Reduction of blood platelet serotonin levels in manic and depressed patients. Folia Psychiatr Neurol Jpn. 1976;30:475-86.

32. Sarrias MJ, Artigas F, Martinez E, Gelpí E, Alvarez E, Udina C, et al. Decreased plasma serotonin in melancholic patients: a study with clomipramine. Biol Psychiatry. 1987;22:1429-38. 
33. Quintana J. Platelet serotonin and plasma tryptophan decreases in endogenous depression. Clinical, therapeutic and biological correlations. J Affect Disord. 1992;24:55-62.

34. Ataoglu A, Canan F. Mean platelet volume in patient with major depression - Effects of escitalopram treatment. J Clin Psychopharmacol. 2009;29:368-71.

35. Martin J, Bath PMW, Burr Ml. Increased platelet size following myocardial infarction is associated with subsequent death and non-fatal reinfarction. Lancet. 1991;338:1409-11.

36. Canan F, Dikici S, Kutlucan A, Celbek G, Coskun $\mathrm{H}$, Gungor A, et al. Association of mean platelet volume with DSM-IV major depression in a large community-based population: The MELEN study. J Psychiatr Res. 2012;46:298-302.

37. Song HR, Jung YE, Wang HR, Woo YS, Jun TY, Bahk WM. Platelet count alterations associated with escitalopram, venlafaxine, and bupropion in depressive patients. Psychiatry Clin Neurosci. 2012;66:457-9.

38. Ishikawa M, Ishiwata K, Ishii K, Kimura Y, Sakata M, Naganawa M, et al. High occupancy of sigma-1 receptors in the human brain after single oral administration of fluvoxamine: A positron emission tomography study using [11C]SA4503. Biol psychiatry. 2007;62:878-83.

39. Fišar Z, Hroudova J, Raboch J. Inhibition of monoamine oxidase activity by antidepressants mood stabilizers. Neuroendocrinology Lett. 2010;31:645-56.

40. Owens MJ, Knight DL, Nemerof CJ. Second generation SSRI's: human monoamine transporter binding profile of escitalopram and R-fluoxetine. Biol Psychiatry. 2001;50:345-50.

41. Hiemke C, Hartter S. Pharmacokinetics of selective serotonin reuptake inhibitors. Pharmacol Ther. 2000;85:11-28.

42. Bymaster FP, Dreshfield-Ahmad LJ, Threlkeld PG, Shaw JL, Thompson L, Nelson DL, et al. Comparative affinity of duloxetine and venlafaxine for serotonin and epinephrine transporters in vitro and in vivo, human serotonin receptors subtypes, and other neuronal receptors. Neuropsychopharmacol. 2001;25:871-80.

43. Mück-Seler D, Pivac N, Šagud M, Jakovljević M, Peleš Mihaljević A. The effects of paroxetine and tianeptine on peripheral biochemical markers in major depression. Prog Neuropsychopharmacol Biol Psychiatry 2002;26:1235-43.

44. De Bodinat C, Guardiola-Lemaitre B, Mocaer E, Renard P, Munoz C, Millan MJ. Agomelatine, the first melatoninergic antidepressant: discovery, characterization and development. Nature Rev Drug Disc. 2010;9:628-42.

45. Isbister GK, Buckley NA. The patophyciology of serotonin toxicity in animals and humans. Clin Neuropharmacol. 2005;28:205-14.

46. Doran CM. Prescribing mental health medication: The practitioners Guide. London: Rouledge, Taylor \& Francis group; 2003.

47. Barefoot JC, Schroll M. Symptoms of depression, acute myocardial infarction, and total mortality in a community sample. Circulation 1996;93:1976-80.

48. Frasure Smith N, Lesperance E, Talajić M. Depression following myocardial infarction: impact on 6-month survival. JAMA. 1993;270:1819-25.

49. Levkovits J, Plow EF, Topol EJ. Platelet glycoprotein IIb/IIIa receptor in cardiovascular medicine. N Engl J Med. 1995;332:1553-9.

50. Camacho A, Dimsdale JE. Platelets and psychiatry: lessions to be learnt from old and new studies. Psychosom Med. 2000;62:326-36.

51. Shah SU, White A, White S, Littler WA. Heart and mind: (1) relationship between cardiovascular and psychiatric conditions. Postgrad Med J. 2004;80:683-9.

52. DeClerck F. Effects of serotonin on platelets and blood vessels. J Cardiovasc Pharmacol. 1991;17:15.

53. Sanner JE, Frazier L, Udtha M. The role of platelet serotonin and depression in the acute coronary syndrome population.Yale J Biol Med. 2013;86:513.

54. Serebruany VL, Gurbel PA, O'Connor CM. Platelet inhibition by sertraline and $\mathrm{N}$-desmethylsertraline: a possible missing link between depression, coronary heart events and mortality benefits of selective serotonin uptake inhibitors. Pharmacol Res. 2001;43:453-62.

55. Pollock BG, Laghrissi-Thode F, Wagner WR. Evaluation of platelet activation in depressed patients with ishemic heart disease treated after paroxetine or nortryptiline treatment. J Clin Psychopharmacol. 2000;20:137-40. 
56. Giles H, Smith REA, Marin JF. Platelet glycoprotein IIb/IIIa and size are increased in myocardial infarction. Eur J Clin Invest. 1994;24:69-72.
57. Tsiara M, Elisaf M, Jagroop IA, Mikhailidis DP. Platelets as predictors of vascular risk: is there a practical index of platelet activity? Clin Appl Throm Hemost. 2003;9:177-90.

\section{Uloga trombocitnog serotoninskog sustava i nekih karakteristika trombocita u liječenju depresivnih pacijenata s kardiovaskularnim bolestima.}

Sažetak - U razvoju depresivnog poremećaja serotonin ima vrlo važnu ulogu. S obzirom da su direktna istraživanja u području centralnog živčanog sustava čovjeka dobrim dijelom nedostupna istraživačima zbog nedostupnosti uzimanja uzoraka, sve veća važnost se pridaje perifernim sustavima koji nam mogu pomoći u dijagnozi, detekciji promjena u samoj bolesti, ali i u praćenju liječenja i oporavka. Trombocit je krvno tjelešce koje u svojim delta granulama sadrži serotonin. Trombocitni serotoninski sustav je sličan, ne i istovjetan serotoninskom sustavu u centralnom živčanom sustavu. Najbitnija je razlika što u trombocitu serotonin razgrađuje enzim monoaminooksidaza B (MAO-B), a u neuronu monoaminooksidaza A (MAO-A), te što trombocit ne može sam sintetizirati serotonin jer mu nedostaje triptofan hidroksilaza. U liječenju depresivnog poremećaja danas se najviše koriste selektivni inhibitori ponovne pohrane serotonina (SIPPS). Istraživanja su dokazala da terapija navedenim lijekovima mijenja koncentraciju serotonina u trombocitima, te mijenja vrijednosti nekih trombocitnih pokazatelja. Trombocitni serotonin je snažan vazokonstriktor, povećava kardiovaskularni rizik i vjerojatnost formiranja tromba. Srednji volumen trombocita (MPV) je pozitivan pokazatelj trombocitne aktivnosti, te je povišeni MPV nezavisni faktor rizika od kardiovaskularnih incidenata. Od izuzetno velike važnosti je prepoznavanje depresije kod pacijenata koji boluju od kardiovaskularnih bolesti. Depresija narušava oporavak tih bolesnika jer reducira osobni angažman u oporavku, suradljivost i motivaciju za liječenje. Osim što liječenje SIPPS-ima dovodi do oporavka simptoma depresije, ono mijenja koncentraciju trombocitnog serotonina i srednji volumen trombocita u smjeru vrijednosti koje smanjuju njihove uloge u patogenezi kardiovaskularnih bolesti čime se smanjuje rizik ponavljanja kardiovaskularnih incidenata i poboljšava se oporavak bolesnika.

Ključne riječi: serotonin, trombociti, SIPPS depresija, kardiovaskularne bolest 